\title{
Wasei eigo (Japlish) pada Buku Teks Bahasa Jepang
}

\author{
Meira Anggia Putri \\ Program Studi Pendidikan Bahasa Jepang \\ Universitas Negeri Padang \\ meira.anggia@fbs.unp.ac.id
}

\begin{abstract}
Abstrak
Artikel ini membahas mengenai wasei eigo yang terdapat pada buku teks bahasa Jepang. Wasei eigo merupakan kosakata yang diciptakan oleh masyarakat Jepang dari bahasa Inggris, namun kata tersebut tidak ditemukan dalam bahasa Inggris standar, atau makna katanya berbeda dari kata bahasa Inggris aslinya. Wasei eigo sangat berkembang dalam bahasa Jepang, sehingga cukup banyak digunakan pada buku-buku teks bahasa Jepang. Akan tetapi perbedaan penggunaan kata dan makna dari wasei eigo dengan kosakata bahasa Inggris asli menjadi permasalahan dalam memahami makna wasei eigo tersebut. Tujuan dari penelitian ini adalah untuk mengetahui wasei eigo apa saja yang terdapat pada buku teks bahasa Jepang, kemudian mengklasifikasikan wasei eigo berdasarkan teori Shibasaki, Tamaoka dan Takatori. Dengan mengetahui klasifikasi dari wasei eigo diharapkan dapat membantu pelajar bahasa Jepang dalam memahami makna dan penggunaan wasei eigo. Jenis penelitian ini adalah kualitatif dengan metode deskriptif. Sumber data penelitian ini adalah buku Minna no nihongo shokyuu1 dan 2. Dari penelitian ini ditemukan 27 data wasei eigo dalam buku teks bahasa Jepang (Minna no Nihongo Shoukyuu 1 and 2). Berdasarkan kategori dari teori Shibasaki, data wasei eigo yang ditemukan terdiri atas 5 data imizurekata, 8 data tanshukukata, 1 data junwaseikata, 4 data eigohyougenfuzaikata, 8 data imizurekata dan tanshukukata, dan 1 data yang termasuk kategori lainnya.
\end{abstract}

Keyword: Wasei eigo, japlish, kata serapan

\section{Abstract}

This study discusses about wasei eigo in Japanese textbook. Wasei eigo are Japanese language expressions that are coined in Japan from English words, that do not exist in Standard English or their meaning differ from the words from which they were derived. 
Wasei eigo grows rapidly in Japanese, hence wasei eigo frequently found in Japanese textbook. But, the difference of wasei eigo from Standard English becomes problem in understanding the meaning of wasei eigo itself. This study aimed to identify wasei eigo among loanwords in Japanese textbook. Then, those words were classified based on theory by Shibasaki, Tamaoka and Takatori. By knowing the classification of the wasei eigo hopefully will help Japanese language learners in understanding the use and the meaning of wasei eigo. The type of research is qualitative research with descriptive method. Data sources for this research are Minna no Nihongo Shoukyuu 1 and 2. This study showed that there are 27 wasei eigo found in Japanese textbook (Minna no Nihongo Shoukyuu 1 and 2). This study found that based on Shibasaki theory, there are 5 datas of wasei eigo which are classified to imizurekata, 8 datas are classified to tanshukukata, 1 data is classified to junwaseikata, 4 datas are classified to eigohyougenfuzaikata, 8 datas are classified to imizurekata and tanshukukata, and last 1 data that is classified to other than the four of categories.

Keyword: Wasei eigo, japlish, loanwords

\section{Pendahuluan}

Dalam bahasa Indonesia banyak terdapat kata-kata yang diserap dari bahasa asing, kata-kata ini disebut dengan kata serapan. Sebagai contoh, kata 'Aktris' merupakan kata serapan dari bahasa Inggris 'Actress', kemudian contoh yang lainnya yaitu, kata 'Suster' merupakan kata serapan dari bahasa Belanda 'Zuster', kata 'Halal' dan 'Haram' merupakan kata serapan dari bahasa Arab, dan banyak lagi kata serapan yang lainnya. Kata-kata serapan ini telah menjadi kata yang baku penggunaannya dalam bahasa Indonesia.

Kata serapan juga terdapat dalam bahasa Jepang, yang juga sangat banyak jumlahnya. Kata-kata serapan dalam bahasa Jepang ini berasal dari berbagai macam bahasa asing, seperti bahasa Inggris, Jerman, Belanda, Perancis, Portugal. Kata serapan tersebut dalam bahasa Jepang disebut dengan Gairaigo, dan dalam bahasa Inggris dikenal dengan istilah loan words. Menurut Dahidi an Sudjianto (2009: 104) gairaigo adalah salah satu jenis kosakata bahasa Jepang yang berasal dari bahasa asing yang telah disesuaikan dengan aturan-aturan yang ada dalam bahasa Jepang. 
Pada sejarahnya, saat Jepang mulai berinteraksi dengan negara-negara Eropa sekitar tahun 1500, masyarakat Jepang memilki kecendrungan untuk menggunakan kata-kata dari bahasa Eropa ke dalam bahasa mereka. Pada awalnya, kata serapan berasal dari bahasa Portugis saat masuknya missionaris-missionaris berkebangsaan Portugis ke Jepang pada abad ke 16. Kemudian pada awal tahun 1600 kata serapan dari bahasa Belanda masuk ke Jepang, yang selanjutnya diikuti oleh bahasa Jerman dan Perancis. Akan tetapi sejak tahun 1900, bahasa Inggris mendominasi kata serapan dalam bahasa Jepang. Pengaruh dari kebudayaan Amerika yang besar terhadap Jepang, mempengaruhi kata-kata yang diserap dari bahasa Inggris ke dalam bahasa Jepang. Olah (2007: 187) mengungkapkan bahwa berdasarkan laporan dari The Japanese National Language Institute pada tahun 1964, menyatakan bahwa 80,8\% kata serapan bahasa Jepang berasal dari bahasa Inggris. Jumlah tersebut masih sangat mungkin untuk terus bertambah karena penggunaannya yang semakin meluas, baik dalam percakapan, pidato, bahasa tulis di media cetak maupun elektronik, serta dalam kesempatan formal maupun informal. Berdasarkan pernyataan tersebut, kata serapan dari bahasa inggris merupakan mayoritas dalam kata serapan bahasa Jepang

Olah (2007: 177) menyebutkan bahwa kata serapan dalam bahasa Jepang merupakan kata yang digunakan oleh masyarakat Jepang yang diambil secara keseluruhan ataupun berasal dari komponen kata-kata dari bahasa lain (di luar bahasa Jepang). Berdasarkan hal tersebut dapat diketahui bahwa kata serapan dalam bahasa Jepang ada yang diambil secara utuh dari bahasa lain dan juga ada yang diambil komponennya dan dibentuk kembali menjadi kata baru. Oleh sebab itu, dapat disimpulkan bahwa dari kata-kata bahasa Inggris yang diserap ke dalam bahasa Jepang tersebut ada yang berasal dari kata yang diambil secara langsung dari bahasa Inggris dengan makna yang sama, sebagai contoh kata バスケットボー ル (Basket Ball) yang berarti 'Bola Keranjang'. Kemudian ada pula kata yang diciptakan dengan mengambil kata dari kosakata bahasa Inggris dan menciptakan kata dengan arti baru yang sama sekali tidak dikenal dalam 
kosakata bahasa Inggris, sebagai contoh, kata イメージアップ (Image up) yang terdiri atas kata イメージ (image) yang dalam bahasa Inggris berarti ‘kesan/tampilan’ dan アップ (up) yang berarti ‘atas/naik', dalam bahasa Inggris kata ini secara harfiah berarti 'naik tampilan', sedangkan dalam bahasa Jepang kata ini berarti 'meningkatkan penampilan' yang dalam bahasa Inggris seharusnya disebut dengan 'creating better image' atau 'enhancing image'. Contoh lainnya kata スマート(smart) dalam bahasa Inggris berarti pintar, akan tetapi dalam bahasa Jepang kata ini memiliki arti 'langsing', makna yang sangat berbeda dari kata bahasa Inggris aslinya.

Kata-kata yang diambil dari kosakata bahasa Inggris dan menciptakan kata dengan arti yang baru yang tidak dikenal dalam bahasa Inggris ini disebut dengan wasei-eigo (Japanized-English). Hal ini sesuai dengan pernyataan Hatanaka dan Panell (2016: 15) bahwa gairaigo merupakan kata yang seutuhnya kata serapan yang diadopsi dari bahasa asing, sedangkan wasei-eigo merupakan kata yang diciptakan di Jepang dari bahasa Inggris.

Akan tetapi walaupun kosakata wasei-eigo berasal dari kata bahasa Inggris, wasei-eigo sulit untuk dipahami oleh penutur asli bahasa Inggris apalagi pembelajar bahasa Jepang sebagai bahasa asing, hal ini disebabkan susunan kata dan makna wasei-eigo berbeda dengan yang digunakan oleh penutur asli bahasa Inggris, oleh sebab itu tanpa melihat kamus bahasa Jepang akan sulit untuk dipahami maknanya. Mc Arthur (2003: 18) menyatakan wasei-eigo adalah kosakata baru yang memiliki makna baru. Sependapat dengan itu, Miller (1997:124) mengatakan bahwa kosakata wasei-eigo, merupakan kata atau gabungan kata yang diciptakan oleh masyarakat Jepang yang berasal dari kata bahasa Inggris yang telah menjadi kosakata bahasa Jepang dengan makna baru yang berbeda dengan makna aslinya. Oleh sebab itu penutur asli bahasa Inggris akan sulit memahami makna dari wasei-eigo, karena penggunaannya kosakatanya hanya digunakan di Jepang. Perbedaan penggunaan kata dan makna bahasa Inggris yang terdapat dalam Wasei-eigo, menjadi salah satu hambatan bagi pembelajar bahasa Jepang sebagai bahasa asing dalam memahami makna 
wasei-eigo dan sebaliknya, penggunaan wasei-eigo yang kerap digunakan dalam bahasa Jepang, menjadi hambatan bagi masyarakat Jepang dalam memahami makna kata bahasa Inggris yang sebenarnya.

Wasei-eigo dapat dikelompokkan berdasarkan bentuk, makna dan karakteristiknya. Menurut Shibasaki, Tamaoka dan Takatori (2007:90) wasei-eigo dapat diklasifikasikan ke dalam empat golongan:

1) Imizurekata (kata yang terdapat dalam bahasa Inggris, tetapi dalam pemakaiannya memiliki arti yang berbeda dengan makna dalam bahasa Inggris).

Contoh: kata スマート'smart' dalam bahasa Inggris kata ini memiliki makna pintar, cerdas akan tetapi dalam bahasa Jepang kata ini bermakna 'langsing', sedangkan dalam bahasa Inggrisnya adalah 'slim'. Kata Wasei-eigo ini terdapat dalam bahasa Inggris akan tetapi memiliki makna yang sangat berbeda dengan kata bahasa Inggris aslinya.

2) Tanshukukata (wasei-eigo yang terbentuk karena pemendekan dari kata bahasa Inggris)

Contoh: kata テレビ ‘terebi’ kata ini merupakan pemendekan dari kata serapan bahasa Inggrisnya yaitu テレビシオン 'television'. Walaupun kata ini diambil dari bahasa Inggris dan memiliki makna yang sama, akan tetapi masyarakat pembicara bahasa Inggris tidak mengenal dan mengetahui kata ini, karena kata ini telah mengalami perubahan yaitu mengalami pemendekan.

3) Junwaseikata (seperti kata dari bahasa Inggris akan tetapi penggunaan katanya tidak ditemukan dalam bahasa Inggris).

Contoh: kata ナイター dari kata Nighter yang memiliki makna 'pertandingan malam' (khususnya pada pertandingan Baseball). Pemakaian kata Nighter ini sama sekali tidak ada 
dalam kata bahasa Inggris.

4) Eigohyougenfuzaikata (gabungan dari beberapa kata morfem bahasa Inggris sehingga menciptakan makna yang baru). Contoh: kata アフターサービス dari kata アフター (After) yang berarti “sesudah” dan サービス (Service) yang berarti "pelayanan", dalam bahasa Inggris secara harfiah gabungan kata ini berarti "Pelayanan Sesudah", akan tetapi bagi masyarakat pembahasa Jepang kata ini bermakna "Pelayanan Pelanggan" yang dalam bahasa Inggris dikenal dengan kata "Costumer Service"

Penggunaan kosakata wasei-eigo ini sering digunakan oleh media massa, majalah busana, majalah wanita dan komik. Penggunaan frasa yang keinggris-inggrisan ini dimaksudkan agar bahasa yang digunakan terlihat lebih menarik dan modern. Seiring berkembangnya penggunaan kosakata wasei-eigo, penggunaan kosakata ini tidak hanya ditemukan pada media cetak saja, namun juga digunakan pada kehidupan sehari-hari dan kosakata wasei-eigo juga banyak ditemukan pada buku teks bahasa Jepang. Penggunaan kosakata wasei-eigo yang kerap hadir pada buku teks bahasa Jepang, membuat pembelajar bahasa Jepang sebagai bahasa asing, terlebih bagi yang sebelumnya telah terlebih dahulu mempelajari bahasa Inggris agak kesulitan dan kebingungan dalam memaknai kosakata waseieigo yang terdapat pada buku teks tersebut.

Salah satu buku teks yang kerap digunakan oleh pembelajar bahasa Jepang di Indonesia adalah buku Minna no Nihongo, khususnya buku Minna no Nihongo Shokyuu 1 dan 2, yang digunakan oleh pembelajar bahasa Jepang tingkat dasar. Dalam buku teks Minna no Nihongo Shoukyuu 1 dan 2 cukup banyak ditemukan kata serapan bahasa Inggris, yang penggunaan katanya tidak ditemukan dalam bahasa Inggris standar atau tidak ada dalam kosakata bahasa Inggris, sehingga cukup membingungkan untuk memahami maknanya. Oleh sebab itu, penelitian ini difokuskan kepada wasei eigo yang terdapat pada buku teks Minna no Nihongo Shoukyuu 1 
dan Minna no Nihongo Shoukyuu 2.

Berdasarkan hal tersebut di atas, tujuan dari penelitian ini adalah untuk mengetahui wasei eigo apa saja yang terdapat pada buku teks bahasa Jepang minna no nihongo shoukyuu 1 dan 2, kemudian untuk mengetahui kategorisasi dari wasei eigo tersebut berdasarkan teori dari Shibasaki, Tamaoka dan Takatori.

\section{Metode Penelitian}

Penelitian ini menggunakan pendekatan kualitatif deskriptif. Penelitian kualitatif mencari makna, pemahaman, pengertian mengenai suatu fenomena, kejadian, maupun kehidupan manusia dengan terlibat secara lagsung/tidak langsung (Yusuf, 2017:328). Sementara itu, penelitian deskriptif adalah penelitian yang berusaha mendeskripsikan suatu gejala, peristiwa, kejadian yang terjadi saat sekarang. Penelitian deskriptif memusatkan perhatian kepada masalah-masalah aktual sebagaimana adanya pada saat penelitian berlangsung (Noor, 2011). Melalui penelitian deskriptif, peneliti berusaha mendeskripsikan peristiwa dan kejadian yang menjadi pusat perhatian tanpa memberikan perlakukan khusus terhadap peristiwa tersebut. Hal ini berarti penelitian deskriptif pada penelitian ini berupaya menjelaskan mengenai kosakata wasei-eigo yang terdapat pada buku ajar bahasa Jepang berdasarkan teori kategorisasi dari Shibasaki, Tamaoka dan Takatori.

Sumber data penelitian ini adalah buku ajar bahasa Jepang yaitu Minna no Nihongo Shokyuu 1 dan 2. Teknik pengumpulan data yang digunakan adalah teknik catat, yaitu dengan mencatat kata-kata serapan yang ada pada buku ajar Minna no Nihongo Shokyuu 1 dan Minna no Nihongo Shokyuu 2, dengan tahapan sebagai berikut: 1) Mencatat kata serapan yang terdapat pada buku ajar bahasa Jepang 2) Mengetahui asal kata dari kata serapan, 3) Mencari makna penggunannya dalam bahasa Jepang dan kata apa yang digunakan untuk mewakili makna tersebut dalam bahasa Inggris asli. 5) Mengidentifikasi wasei eigo dari kata serapan bahasa Inggris yang ditemukan

Selanjutnya analisis data dilakukan dengan tahapan sebagai berikut, 
1) Menganalisis dan mengklasifikasikan data berdasarkan teori Shibasaki, Tamaoka dan Takatori. 3) Membahas temuan dan 3) Membuat kesimpulan.

\section{Hasil Penelitian dan Pembahasan}

Berdasarkan kata serapan yang telah dikumpulkan, setelah dipilah ditemukan 27 data yang merupakan wasei eigo, yang dapat dilihat pada tabel berikut:

Tabel 1. Data wasei eigo pada Minna no Nihongo Shokyuu 1 dan 2

\begin{tabular}{|c|c|c|c|c|}
\hline No & Wasei eigo & Asal kata & Makna wasei & Bahasa Inggris \\
\hline 1 & $\begin{array}{l}\text { シャープペ } \\
\text { シシル } \\
\text { (Shaapu } \\
\text { Penshiru) }\end{array}$ & $\begin{array}{l}\text { Sharp + } \\
\text { Pencil }\end{array}$ & Pensil Mekanik & $\begin{array}{l}\text { Mechanical } \\
\text { pencil }\end{array}$ \\
\hline 2 & $\begin{array}{l}\text { デパート } \\
\text { (Depaato) }\end{array}$ & $\begin{array}{l}\text { Depart(ment } \\
\text { Store) }\end{array}$ & $\begin{array}{l}\text { Pusat } \\
\text { perbelanjaan }\end{array}$ & $\begin{array}{l}\text { Departement } \\
\text { Store }\end{array}$ \\
\hline 3. & (Suupaa) & Super(market) & $\begin{array}{l}\text { Pasar } \\
\text { Swalayan }\end{array}$ & Super market \\
\hline 4. & $\begin{array}{l}\text { (waapuro) } \\
\text { (w) }\end{array}$ & $\begin{array}{l}\text { Wo }(\text { rd }) \\
\text { Pro(cessor) }\end{array}$ & $\begin{array}{l}\text { Mesin } \\
\text { Pengolah Kata }\end{array}$ & $\begin{array}{l}\text { Word } \\
\text { Processor }\end{array}$ \\
\hline 5. & (Pasokon) & $\begin{array}{l}\text { Per(sonal) } \\
\text { Com(puter) }\end{array}$ & $\begin{array}{l}\text { Perangkat } \\
\text { komputer yang } \\
\text { digunakan oleh } \\
\text { pribadi }\end{array}$ & $\begin{array}{l}\text { Personal } \\
\text { Computer }\end{array}$ \\
\hline 6 & $\begin{array}{l}\text { ホッチキス } \\
\text { (Hocchikisu) }\end{array}$ & $\begin{array}{l}\text { Hotchkiss } \\
\text { (nama } \\
\text { penemu) }\end{array}$ & Stapler & Stapler \\
\hline 7 & $\begin{array}{l}\text { カラオケ } \\
\text { (Karaoke) }\end{array}$ & $\begin{array}{l}\text { Kara: } \\
\text { empty) }+ \\
\text { Orche(stra) }\end{array}$ & Karaoke & Karaoke \\
\hline 8 & $\begin{array}{l}\text { ポスト } \\
\text { (Posuto) } \\
\text { Pontul (Binul }\end{array}$ & Post(box) & Kotak surat & $\begin{array}{l}\text { Postbox (US) } \\
\text { Mailbox (Eng) }\end{array}$ \\
\hline$\frac{9}{10}$ & $\begin{array}{l}\text { EJ (Biru) } \\
\text { (E) } \\
\text { (Eakon) }\end{array}$ & $\begin{array}{l}\text { Buillding) } \\
\text { Air } \\
\text { Con(ditioner) }\end{array}$ & $\begin{array}{l}\text { Gedung } \\
\text { Alat untuk } \\
\text { mengatur suhu }\end{array}$ & $\begin{array}{l}\text { Building } \\
\text { Air } \\
\text { conditioner }\end{array}$ \\
\hline 11. & $\begin{array}{l}\text { ソフト } \\
\text { (Sofuto) }\end{array}$ & Soft(ware) & $\begin{array}{l}\text { Perangkat } \\
\text { lunak }\end{array}$ & Software \\
\hline 12. & $\begin{array}{l}\text { ガイド } \\
\text { (Pureigaido) }\end{array}$ & Play + Guide & $\begin{array}{l}\text { Tempat } \\
\text { penjualan } \\
\text { karcis (bioskop } \\
\text { dll) }\end{array}$ & $\begin{array}{l}\text { (theater) ticket } \\
\text { agency }\end{array}$ \\
\hline 13 & $\begin{array}{l}\text { サフリ } \\
\text { ーマン } \\
\text { (Sarariiman) }\end{array}$ & Salary + man & Pekerja kantor & Office worker \\
\hline
\end{tabular}




\begin{tabular}{|c|c|c|c|c|}
\hline 14 & $\begin{array}{l}\text { ラッシュ } \\
\text { (Rasshu) }\end{array}$ & Rush (hour) & Jam sibuk & Rush hour \\
\hline 15 & $\begin{array}{l}\text { ワソヒース } \\
\text { (wanniisu) }\end{array}$ & One-piece & Gaun & Dress \\
\hline 16 & $\begin{array}{l}\text { (Manshon) } \\
\text { (MY }\end{array}$ & Mansion & $\begin{array}{l}\text { Apartemen, } \\
\text { kondominium }\end{array}$ & Condominium \\
\hline 17 & $\begin{array}{l}\text { ニング } \\
\text { ニンuriiningur }\end{array}$ & Cleaning & Laundry & Laundry \\
\hline 18. & $\begin{array}{l}P=X \\
\text { (Anime) }\end{array}$ & Anima(tion) & Kartun animasi & $\begin{array}{l}\text { Animated } \\
\text { cartoon }\end{array}$ \\
\hline 19. & 不分 (Nega) & Nega(tive) & $\begin{array}{l}\text { Negatif } \\
\text { (fotografi) }\end{array}$ & $\begin{array}{l}\text { (Photography) } \\
\text { negative }\end{array}$ \\
\hline 20 & $\begin{array}{l}\text { コンビニ } \\
\text { (Konbini) }\end{array}$ & $\begin{array}{l}\text { Conveni(ence } \\
\text { store) }\end{array}$ & Toko serba ada & $\begin{array}{l}\text { Convenience } \\
\text { Store }\end{array}$ \\
\hline 21 & (Furonto) & Front (desk) & Resepsionis & $\begin{array}{l}\text { Front } \\
\text { (reception) } \\
\text { desk }\end{array}$ \\
\hline 22 & $\begin{array}{l}\text { ドフイバー } \\
\text { (Doraiba-) }\end{array}$ & Driver & Obeng & Screw driver \\
\hline 23 & $\begin{array}{l}\text { (Mikisa-) } \\
\text { (Mikis- }\end{array}$ & Mixer & Blender & Blender \\
\hline 24 & (Panchi) & $\begin{array}{l}\text { (hole) } \\
\text { Punch(er) }\end{array}$ & $\begin{array}{l}\text { Alat } \\
\text { pembolong } \\
\text { kertas }\end{array}$ & Hole puncher \\
\hline 25 & $\begin{array}{l}\text { パ下カー } \\
\text { (Patokaa) }\end{array}$ & Pat(rol) car & Mobil patrol & Patrol Car \\
\hline 26 & 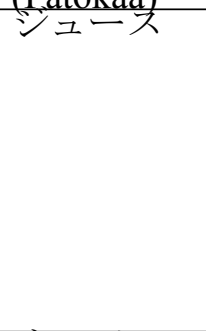 & Juice & $\begin{array}{l}\text {-Sari buah } \\
\text { - Minuman } \\
\text { campuran sari } \\
\text { buah } \\
\text { - Minuman } \\
\text { bersoda } \\
\text { - Minuman } \\
\text { ringan }\end{array}$ & $\begin{array}{l}\text { Juice } \\
\text { Soft drink } \\
\text { Carbonated } \\
\text { drink }\end{array}$ \\
\hline 27 & サービス & Service & $\begin{array}{l}\text { - Pelayanan } \\
\text { - Jasa } \\
\text { - Memberikan } \\
\text { pelayanan } \\
\text { ekstra seperti } \\
\text { pemberian } \\
\text { bonus, diskon } \\
\text { atau peniadaan } \\
\text { biaya }\end{array}$ & $\begin{array}{l}\text { - Service } \\
\text { - Provide } \\
\text { something } \\
\text { extra } \\
\text { (throwing in } \\
\text { free of charge) }\end{array}$ \\
\hline
\end{tabular}

Kemudian wasei-eigo diklasifikasikan menurut teori Shibasaki, Tamaoka dan Takatori (2007) ke dalam 4 golongan, yaitu: Imizurekata, 
Tanshukukata, Junwaseikata dan Eigohyougenfuzaikata.

\section{a. Imizurekata}

Imizurekata adalah golongan wasei eigo yang merupakan kata yang terdapat dalam bahasa Inggris, tetapi dalam pemakaiannya memiliki makna yang berbeda dengan makna dalam bahasa Inggris asli. Dari 27 data wasei eigo, ditemukan 5 data yang termasuk ke dalam kelompok ini, yaitu: マンション (mansion), ミキサー (mixer), ジュース (juice), サービス (service), クリーニング(cleaning). Salah satu contoh analisis data untuk golongan ini adalah sebagai berikut:

Data (16)

このマンションでペットが飼えますか。

小さい鳥や魚が飼えますが、犬や猫は飼えません。

Kono manshon de petto ga kaemasuka.

chiisai tori ya sakana ga kaemasuga, inu ya neko ha kaemasen.

(Minna no Nihongo Shokyuu 2: hal 10)

Pada data (16) terdapat kata マンション (manshon) yang merupakan kata serapan dari kata bahasa Inggris yaitu mansion. Akan tetapi, makna kata mansion dalam bahasa Jepang sangat berbeda dengan makna kata mansion dalam bahasa Inggris. Dalam bahasa Jepang kata mansion didefinisikan sebagai apartemen, flat atau kondominium, sedangkan dalam bahasa Inggris mansion bermakna rumah besar yang megah. Pada data kalimat (16) di atas, diketahui bahwa pada mansion tidak diperbolehkan untuk memelihara binatang seperti kucing dan anjing, peraturan hal ini diketahui umumnya hanya ada pada rumah susun, apartemen atau kondominum, berbeda dengan di mansion dalam budaya pembahasa Inggris asli, dimana larangan dalam memelihara binatang seperti kucing dan anjing, tergantung kepada pemilik mansion tersebut. Oleh sebab itu, terdapat perbedaan baik secara makna maupun fungsi dalam penggunaan kata mansion dalam bahasa Jepang dan Inggris. Secara lebih jelas dapat dilihat pada tabel berikut: 
Tabel 2. Wasei eigo manshon

\begin{tabular}{|l|l|l|l|}
\hline Wasei eigo & $\begin{array}{l}\text { Asal kata } \\
\text { serapan }\end{array}$ & $\begin{array}{l}\text { Makna dalam } \\
\text { bahasa Jepang }\end{array}$ & $\begin{array}{l}\text { Makna dalam bahasa } \\
\text { Inggris }\end{array}$ \\
\hline $\begin{array}{r}\text { マンシ } \\
\text { Mansion }\end{array}$ & $\begin{array}{l}\text { Kondominium, } \\
\text { apartemen, flat }\end{array}$ & Rumah besar megah \\
\hline
\end{tabular}

Dari tabel 2. Dapat diketahui bahwa perbedaan penggunaan kata mansion antara bahasa Jepang dan bahasa Inggris sangat signifikan. Walaupun kata mansion berasal dari bahasa Inggris, penutur bahasa Inggris sebagai bahasa ibu tidak menggunakan kata mansion untuk menyatakan apartemen, melainkan apartment atau condominium. Berdasarkan hal tersebut, wasei eigo マンション (manshon) dikategorikan kedalam bentuk imizurekata.

\section{b. Tanshukukata}

Tanshukukata merupakan golongan wasei-eigo yang terbentuk karena pemendekan dan pelesapan. Dari 27 data wasei eigo, ditemukan 8 data yang tergolong ke pada kategori ini, yaitu: ワープロ (waapuro)、 パソコン (pasokon)、ビル (biru)、エアコン(eakon)、アニメ(anime) 、ネガ(negative)、コンビニ (konbini)、パトカー.(patokaa). Salah satu analisis data untuk golongan ini, sebagai berikut

Data (9)

あそこにビルがあります。

Asoko ni biru ga arimasu.

(Minna no Nihongo Shoukyuu 1: hal 82)

Pada kalimat data (9) terdapat kata ビル (biru). Kata ini mengalami pemenggalan dari kata awal birudingu, yang merupakan kata serapan bahasa Inggris building. Secara makna tidak ada perbedaan pada kata biru dalam bahasa Jepang dengan building dalam bahasa Inggris, keduanya sama-sama menyatakan 'bangunan', hanya saja kata biru merupakan pemenggalan dari kata building. Untuk lebih jelasnya dapat dilihat pada 
tabel berikut:

Tabel 3. Wasei eigo biru

\begin{tabular}{|l|l|l|l|}
\hline Wasei eigo & Asal kata & $\begin{array}{l}\text { Makna dalam } \\
\text { bahasa Jepang }\end{array}$ & $\begin{array}{l}\text { Makna dalam } \\
\text { bahasa Inggris }\end{array}$ \\
\hline ビル(biru) & $\begin{array}{l}\text { Buil(ding) (dalam } \\
\text { aturan pengucapan } \\
\text { bahasa Jepang } \\
\text { dibaca birudingu) }\end{array}$ & $\begin{array}{l}\text { B a n g n a n } \\
\text { bertingkat }\end{array}$ & Semua bangunan \\
\hline
\end{tabular}

Dari tabel 3 di atas dapat diketahui bahwa kata biru terbentuk dari kata building yang mengalami penghilangan silabel akhir, yaitu silabel/suku kata 'ding'. Dari tabel ini juga diketahui bahwa tidak ada perbedaan makna dari biru dan building, yang keduanya sama-sama menyatakan makna 'bangunan'. Walaupun sama-sama menyatakan makna bangunan, pemenggalan kata building menjadi biru dalam bahasa Jepang, menyebabkan kata yang digunakan berbeda dengan kata yang digunakan oleh penutur asli bahasa Inggris. Karenanya, masyarakat penutur asli bahasa Inggris tidak mengenal kata biru, walaupun seperti yang telah disebutkan sebelumnya, bahwa kata biru ini merupakan pemenggalan dari kata bahasa Inggris. Hal ini tentu saja dikarenakan kata biru ini dibuat oleh masyarakat Jepang dan hanya digunakan oleh masyarakat Jepang pula. Berdasarkan hal tersebut kata biru merupakan wasei eigo yang tergolong pada kategori tanshukukata.

\section{c. Junwaseikata}

Junwaseikata merupakan kategori wasei eigo yang penggunaan katanya tidak ditemukan dalam bahasa Inggris namun dianggap seperti kata yang ada dalam bahasa Inggris. Dari 27 data wasei eigo, hanya ditemukan satu data yang termasuk ke dalam kategori ini, yaitu kata ホッ チキス (hocchikisu). Analisis data untuk wasei eigo yang diklasifikasikan kepada kategori ini adalah sebagai berikut:

$$
\begin{aligned}
& \text { Data (6) } \\
& \text { これは日本語で何ですか。 }
\end{aligned}
$$




\section{ホッチキスです。}

(Minna no Nihongo Shoukyuu 1: hal 61)

Pada data (6) terdapat kata hocchikisu yang dalam bahasa Jepang bermakna alat untuk menjepit kertas yang berisi staples. Tanpa mengetahui makna dari kata ini, kata ini terlihat dan terdengar seperti kata serapan dari bahasa Inggris. Akan tetapi dalam kosakata bahasa Inggris tidak terdapat dan tidak dikenal kata Hocchikisu untuk menyatakan alat untuk menjepit kertas yang berisi staples, akan tetapi kata yang digunakan adalah Stapler. Untuk lebih jelasnya dapat dilihat pada tabel berikut:

Tabel 4. Wasei eigo hocchikisu

\begin{tabular}{|l|l|l|l|}
\hline Wasei eigo & Asal kata & Makna yang dituju & $\begin{array}{l}\text { Kata dalam bahasa } \\
\text { Inggris }\end{array}$ \\
\hline $\begin{array}{r}\text { ホッチキ } \\
\text { スotchkiss }\end{array}$ & $\begin{array}{l}\text { alat untuk menjepit } \\
\text { kertas yang berisi } \\
\text { staples }\end{array}$ & Stapler \\
\hline
\end{tabular}

Dari tabel 4 diketahui bahwa kata hocchikisu berasal dari kata Hotchkiss. Kata Hotchkiss tidak ada dalam kamus bahasa Inggris. Kata ini merupakan kata yang diambil dari penemu alat itu sendiri, yang oleh masyarakat Jepang digunakan untuk menyatakan alat/temuannya, yaitu alat untuk menjepit/menyatukan kertas berisi staples, yang oleh penutur asli bahasa Inggris dikenal dengan kata stapler. Masyarakat pengguna bahasa Inggris sebagai bahasa ibu tidak memahami makna Hotchkiss dan kata tersebut juga tidak ada pada kata bahasa Inggris. Hal ini karena masyarakat Jepanglah yang menciptakan kata tersebut. Walaupun seperti kata serapan bahasa Inggris, namun kata ini tidak terdapat pada bahasa Inggris, maka wasei eigo ini digolongkan kepada kategori Junwaseikata.

\section{d. Eigohyougenfuzaikata}

Eigohyougenfuzaikata merupakan kategori wasei eigo yang katanya terdiri dari gabungan dari beberapa morfem/kata bahasa Inggris yang membentuk makna baru. Dari 27 data wasei eigo ditemukan 4 data wasei eigo yang termasuk ke dalam eigohyougenfuzaikata, yaitu ワンピ 
ース (wanpi-su), シャープペンシル (shaapu penshiru), サラリーマン (sararii man), プレイガイド (purei gaido). Salah satu analisis dari data yang ditemukan untuk golongan ini adalah sebagai berikut:

Data (13)

私はサラリーマンだ。

Watashi ha sarariiman $d a$.

(Minna no Nihongo Shoukyuu 1: hal 166)

Pada data (13) terdapat kata サラリーマン (sarariiman), yang merupakan kata serapan dari bahasa Inggris. Kata ini merupakan gabungan dari dua morfem bahasa Inggris, yaitu dari kata サラリー (salary) dan マン (man). Kata sarariiman ini digunakan oleh masyarakat Jepang untuk menyatakan pekerja kantoran atau pegawai perusahaan. Penutur asli bahasa Inggris tidak menggunakan kata ini dalam berkomunikasi dan dalam kosakata bahasa Inggris sama sekali tidak ada kata sarariiman. Untuk lebih jelasnya dapat dilihat pada tabel berikut:

Tabel 5. Wasei eigo Sarariiman

\begin{tabular}{|l|l|l|l|}
\hline Wasei eigo & Asal kata & $\begin{array}{l}\text { Makna dalam } \\
\text { bahasa Jepang }\end{array}$ & $\begin{array}{l}\text { P e ng u n a a n } \\
\text { dalam bahasa } \\
\text { Inggris }\end{array}$ \\
\hline $\begin{array}{l}\text { サラリー } \\
\text { マン } \\
\text { Sarariiman }\end{array}$ & $\begin{array}{l}\text { Salary } \\
\text { Man }\end{array}$ & $\begin{array}{l}\text { Pekerja kantoran/ } \\
\text { pegawai perusahaan }\end{array}$ & Office worker \\
\hline
\end{tabular}

Pada tabel 5 dapat diketahui bahwa terdapat perbedaan penggunaan kata yang menyatakan pekerja kantoran/pegawai perusahaan antara bahasa Jepang dengan bahasa Inggris. Walaupun kata salaryman merupakan kata yang berasal dari gabungan morfem bahasa Inggris, tetapi dalam bahasa Inggris tidak menggunakan kata salaryman untuk menyatakan makna pekerja kantoran/pegawai perusahaan. Kata yang digunakan dalam bahasa Inggris untuk menyatakan makna ini adalah office worker/ company employee. Kata salaryman merupakan kata yang diciptakan oleh masyarakat Jepang dengan menggabungkan dua morfem bahasa Inggris, sehingga 
membentuk makna baru yang tidak dikenal dalam bahasa Inggris. Oleh sebab itu, wasei eigo salaryman tergolong kepada eigohyougenfuzaikata.

\section{e. Imizurekata dan Tanshukukata}

Dari 27 data wasei eigo yang dianalisis juga ditemukan juga 8 data yang termasuk kedalam Imizurekata (kata yang terdapat dalam bahasa Inggris, tetapi dalam pemakaiannya memiliki makna yang berbeda dengan makna dalam bahasa Inggris) dan Tanshukukata (wasei-eigo yang terbentuk karena pemendekan). Data-data yang termasuk kedalam kategori ini adalah, デパート(depaato)、スーパー (suupaa)ポスト (posuto), ソフト (sofuto), ラッシュ (rasshu), フロント (furonto), ドライバー (doraibaa) dan パンチ (panchi). Salah satu analisis data untuk golongan ini, sebagai berikut:

Data (22)

$$
\text { ドライバーを貸しませんか }
$$

Doraibaa wo kashimasenka

(Minna no Nihongo Shoukyuu 2: hal 135)

Pada kalimat data 22 ditemukan kata doraibaa. Kata ini merupakan kata yang diserap dari bahasa Inggris driver. Akan tetapi makna yang dituju pada kalimat ini berbeda dengan kata driver yang ada pada dalam bahasa Inggris. Pada data kalimat ini, kata driver bermakna obeng, yang dalam bahasa Inggris kata yang digunakan untuk menyatakan makna ini adalah screw driver. Diketahui bahwa dalam bahasa Jepang terdapat penghilangan morfem screw dari kata screw driver, sehingga kata yang digunakan hanya kata driver. Untuk lebih jelasnya dapat dilihat pada tabel berikut:

Tabel 6. Wasei eigo doraibaa

\begin{tabular}{|l|l|l|l|l|l|}
\hline $\begin{array}{l}\text { Wa se } i \\
\text { eigo }\end{array}$ & $\begin{array}{l}\text { Cara baca } \\
\text { dalam bahasa } \\
\text { Inggris }\end{array}$ & $\begin{array}{l}\text { Makna bahasa } \\
\text { Inggris }\end{array}$ & $\begin{array}{l}\text { Makna } \\
\text { y a } \mathrm{g} \\
\text { dituju }\end{array}$ & $\begin{array}{l}\text { Kata dalam } \\
\text { Inggris }\end{array}$ \\
\hline
\end{tabular}




\begin{tabular}{|l|l|l|l|l|}
\hline ドライ & Driver & - Pengemudi & Obeng & Screw driver \\
- Perangkat & & & \\
& & lunak komputer & & \\
& & yang mengontrol & & \\
input dan output & & \\
& & operasi komputer & & \\
& & - Penggerak & & \\
& & - Alat pemukul & & \\
& & dalam Golf & & \\
\hline
\end{tabular}

Dari tabel 6. diketahui bahwa kata driver yang digunakan bermakna 'obeng', merupakan kata serapan dari bahasa Inggris yaitu screw driver, kata ini telah mengalami penghilangan morfem awal dari kata bahasa Inggris tersebut yaitu morfem screw, sehingga meninggalkan kata driver. Kata driver tidak digunakan untuk menyatakan obeng dalam bahasa Inggris, kata obeng dalam bahasa Inggris adalah screw driver. Penggunaan kata driver saja memiliki makna yang berbeda dalam bahasa Inggris, sehingga penggunaan kata driver dalam bahasa Jepang yang menyatakan obeng dapat membuat mispersepsi bagi penutur asli bahasa Inggris. Kata driver untuk menyatakan obeng ini diciptakan oleh masyarakat bahasa Jepang dan hanya digunakan dalam bahasa Jepang. Berdasarkan hal tersebut wasei eigo ini tergolong kepada imizurekata dan tanshukukata.

\section{f. Penggabungan morfem bahasa Jepang dan morfem bahasa Inggris yang mengalami penyingkatan.}

Dari 27 data wasei eigo, juga ditemukan satu data yang tidak termasuk ke dalam 4 kategori wasei eigo menurut Shibasaki, Tamaoka dan Takatori, yaitu kata カラオケ (karaoke). Dapat dilihat pada data kalimat berikut:

$$
\begin{aligned}
& \text { Data (7) } \\
& \text { カラオケが好きですか。 }
\end{aligned}
$$

Karaoke ga suki desuka

(Minna no Nihongo Shoukyuu 1: hal 77)

Kata カラオケ (karaoke) merupakan gabungan antara dua morfem, 
yaitu morfem bahasa Jepang kara yang berarti kosong dan oke yang merupakan singkatan dari morfem bahasa Inggris orchestra. Untuk lebih jelasnya dapat dilihat pada tabel berikut:

Tabel 7. Wasei eigo karaoke

\begin{tabular}{|c|l|l|l|}
\hline Wasei eigo & Asal kata & Makna kata & $\begin{array}{l}\text { Kata dalam bahasa } \\
\text { Inggris }\end{array}$ \\
\hline $\begin{array}{c}\text { カラオケ } \\
\text { (Karaoke) }\end{array}$ & $\begin{array}{l}\text { Kara (bahasa } \\
\text { Jepang: } \\
\text { kosong) }+ \\
\text { Orchestra } \\
\text { (bahasa }\end{array}$ & $\begin{array}{l}\text { Sebuah bentuk } \\
\text { hiburan di } \\
\text { mana seseorang } \\
\text { menyanyi } \\
\text { diiringi dengan }\end{array}$ & Karaoke \\
& Inggris) & $\begin{array}{l}\text { musik dan } \\
\text { teks lirik yang } \\
\text { ditunjukkan } \\
\text { pada sebuah } \\
\end{array}$ & \\
& & layar televisi. & \\
\hline
\end{tabular}

Dari tabel 7 diketahui bahwa kata karaoke merupakan gabungan dari morfem bahasa Jepang kara yang berarti kosong dan morfem bahasa Inggris oke yang merupakan pemenggalan kata bahasa Inggris orchestra yang berarti orkestra, sehingga gabungan katanya apabila diartikan secara literal menjadi orkestra kosong. Hal ini sesuai dengan pernyataan dari Quackenbush dan Higa (dalam Miller, 1997: 126) yang menyatakan bahwa beberapa wasei eigo ada yang terbentuk dari morfem bahasa Jepang dan morfem bahasa Inggris.

Kata karaoke ini bermakna sebuah hiburan di mana seseorang menyanyi diiringi dengan musik dan teks lirik yang ditunjukkan pada sebuah layar televisi. Kata karaoke merupakan kata yang diciptakan oleh masyarakat Jepang, dengan memasukkan bahasa Inggris ke dalam unsur katanya. Walaupun begitu, kata karaoke telah menjadi kosakata yang mendunia, bahkan kata karaoke ini pun digunakan dalam bahasa Inggris dan juga bahasa Indonesia. 


\section{Simpulan}

Penelitian ini membahas mengenai wasei eigo pada buku teks bahasa Jepang, yang dibatasi pada buku teks Minna no Nihongo Shoukyuu 1 dan 2. Sesuai dengan tujuan penelitian, penulis mengidentifikasi apaapa saja wasei eigo yang terdapat pada buku teks bahasa Jepang tersebut, kemudian mengklasifikasikannya berdasarkan teori dari Shibasaki, Tamaoka dan Takatori (2007). Dari hasil analisis data dan pembahasan, maka dapat diambil simpulan terkait wasei eigo pada buku teks bahasa Jepang Minna no Nihongo Shokyuu 1 dan 2, yaitu dari 27 data wasei eigo yang ditemukan 5 data termasuk imizurekata, 8 data tanshukukata, 1 data junwaseikata, 4 data eigohyougenfuzaikata, 8 data gabungan dari imizurekata dan eigohyougenfuzaikata, dan 1 data selain empat klasifikasi tersebut yaitu wasei eigo yang terbentuk dari penggabungan morfem bahasa Jepang dan bahasa Inggris, atau bisa disebut dengan loan blend. Dari temuan penelitian ini diketahui bahwa wasei eigo tanshukukata dan gabungan dari imizurekata dan tanshukukata merupakan data wasei eigo yang terbanyak ditemukan pada buku ajar Minna no Nihongo 1 dan 2 . Masyarakat Jepang cendrung memendekkan kata-kata dalam banyak hal dan situasi, khususnya pada kata serapan bahasa asing, Dahidi dan Sudjianto (2009) menyatakan dikarenakan ketiadaan huruf mati pada bahasa Jepang membuat banyak kata serapan menjadi lebih panjang, sehingga untuk membuatnya lebih efektif dan efisien, masyarakat Jepang cenderung memendekkan kata-kata yang diserap dari bahasa asing. Proses pemendekan yang terjadi pada wasei eigo mengakibatkan perubahan makna dari bahasa Inggris aslinya.

\section{Referensi}

Dahidi, Ahmad dan Sudjianto. 2009. Pengantar Linguistik Bahasa Jepang. Jakarta: Kesaint Blanc.

Hatanaka, Mariko dan Panell, Justin. 2016. "English Loan Words and Made in Japan English in Japanese" Jurnal Hawaii Pacific University TESOL, Vol 14, pp 14-29. 
Olah, Ben. 2007. "English Loan Words in Japanese: Effects, Attitudes, and Usage as Means of Improving English Spoken Ability" Jurnal Bukyou Gakuin Daigaku Ningen Gakubu Kenkyuu Kiyou. Vol. 9, No. 1, pp 177-188

Mc Arthur, Thomas B. 2003. The English Language. New York:

Cambridge University.

Miller, Laura. 1997. "Wasei-eigo: English "loanwords" coined in Japan" In The life of language: Papers in linguistics in honor of William Bright. The Hague: Mouton de Gruyter, pp 123-139

Shibasaki, Tamaoka dan Takatori. 2007. “Amerikajin wa Wasei-eigo wo Donogurai Rikai Dekiruka" Nihon-go Kagaku [Japanese Linguistics] (The National Institute for Japanese Language) 21, pp 89-110.

Noor, Juliansyah. 2011. Metodologi Penelitian: Skripsi, Tesis, Disertasi dan Karya Ilmiah. Jakarta: Kencana.

Yusuf, A. Muri. 2017. Metode Penelitian Kuantitatif, Kualitatif dan Penelitian Gabungan. Jakarta: Kencana

. 1998. Minna No Nihongo I (Shokyuu I). Japan: 3A Corporation.

.2013. Minna No Nihongo II (Shokyuu II). Japan: 3A Corporation.

https://ejje.weblio.jp/

https://www.merriam-webster.com/ 